\title{
AWAKENING WITH THE BHAGAVAD GITA
}

\section{DR KU. RICHASHRIVASTAVA}

Scholar, IITR, Roorkee, Ruchilifescape, Jatkhedi, Hoshangabad Road, Bhopal, Madhya Pradesh, India

\begin{abstract}
Whenever human beings get anxious owing to their plights, adversities, major predicaments and limitations, a person does not get that what they have anticipated, yearned, suchlike gain we have estimated if we do not acquire that profit. The high - esteem which we ought to get-if we do not get that honour, we preferred the fortune in our favour to meet someone special, if we do not meet that someone special in our life. If we deserved the victory, we did not become victorious. If we wanted to be with our near and dear but we may not be able to get their companionship - whenever these incidents are faced by the individual, the person gets depressed in life.
\end{abstract}

KEYWORDS: Bhagavad Gita, Depresssion, Victory

Received: Aug 19, 2020; Accepted: Sep 09, 2020; Published: Sep 22, 2020; Paper Id.: IJESRAUG202011

\section{INTRODUCTION}

Depression diminishes our efficiency; depression challenges our bravery, whenever we get depressed our rigorous energy does not work. Depression constantly has impinged on our wisdom. Our intellect does not work, then, what we have to do and what else not to be done? Whenever we are depressed, we get confounded and then after, we deflect away from our path. It is likely if we will stand in a crossroad and then, we would not be able to perceive either to move forward or to get backward, whether to go left or to go right.

Arjun is also in the same proviso. Depressed Arjun implies different points of views- there will be war, soldiers will die, and many married women will become widows. Women's dignity will be degraded. The children would not learn good moral values. Inter-religious marriages will take place. War is furious, it is better not to fight the war - all these reasons are suggested by Arjun. He wishes to speak out that he does not want bloodshed. The throne that is won after the massive killing of millions of innocents; he does not feel like to rule over that throne. He does not allow himself to take the blame for so many deaths. Thereby, he is saddened to leave the empire. Even if Kauravas murder him, he ponders that to be a beggar is better instead of all these situations; he refused to fight the war. 


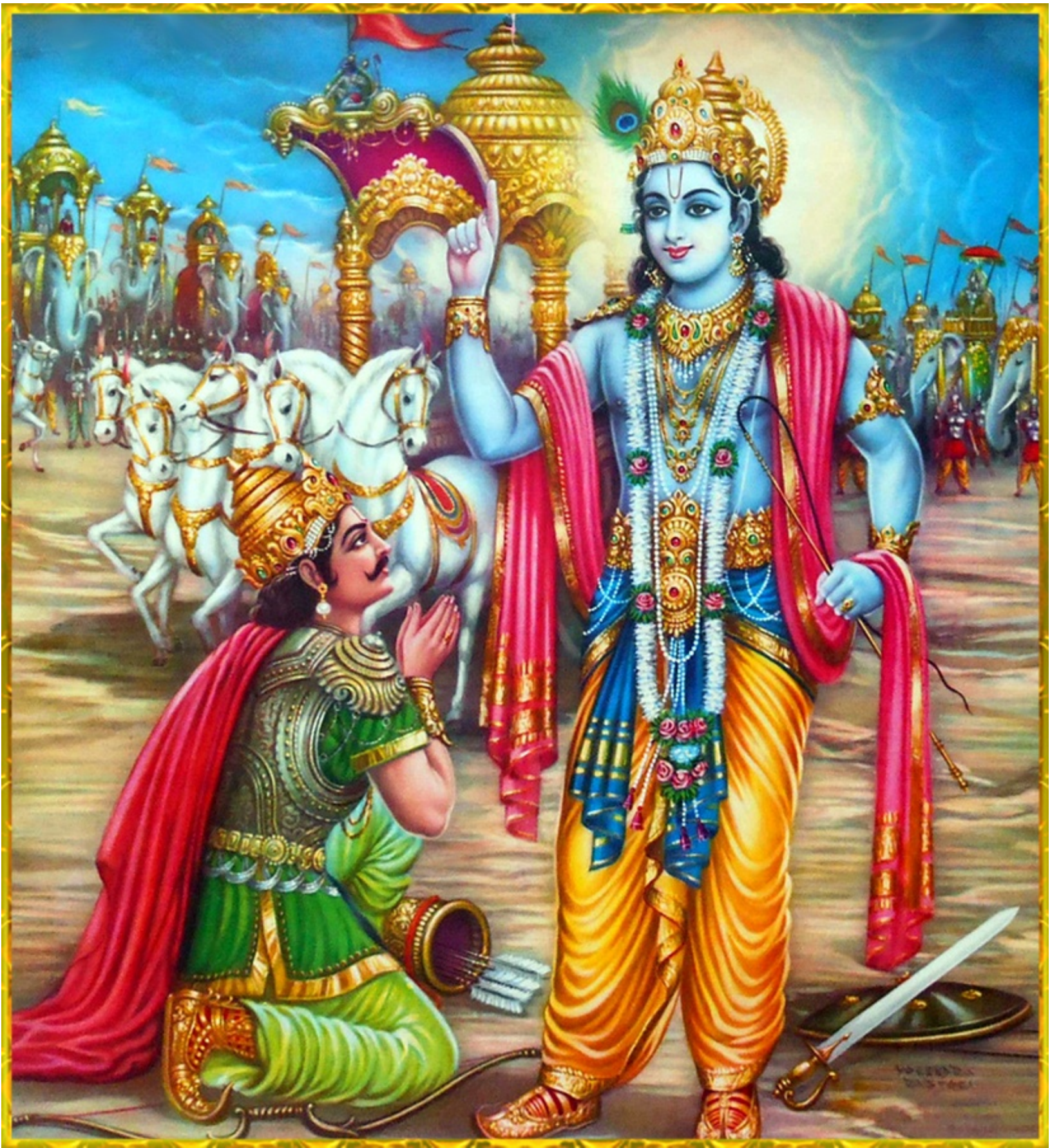

Figure 1: Lord Krishna and Arjun in the Battlefield.

For the time has been, Arjun has this effect on his mind. Whenever the person gets dejected, he escapes from fulfilling his obligations. The way a person suffers, he expresses himself in that manner. Lord Krishna answers and elucidates Arjun, amid darkness in his life; he enlightens him with the knowledge. In his mind, all the miserable deliberations exist. Lord Krishna encourages him with the optimism and the affirmation. Lord Krishna acknowledges him with his accountabilities. Lord Krishna states that "Oh Arjun! This annoyance gets within you with very complicated situations. Oh, Arjun! This frustration and depression should not be the outcome of a great person like you! These consequences of your deeds would not seize you to heaven; it will lessen your eminence. If you will not fight with this situation, you will be called a coward". Furthermore, Krishna emphasis that even after Arjun arrives in the battlefield and 
after the observation of the army, if he runs away from the combat zone, this is not correct. The whole society is standing with him. He must countenance the warfare bravely, otherwise, all the evil powers are standing bravely against him, and he ought to subdue them.

As we all know that when farmers plant the pulses, they remove the weeds and the grass. The wild grasses which are worthless, that would surpass the growth of important cereals. Then, the plantations of food grains would not flourish. That is why the farmers have to remove weeds for the cultivation of useful cereals. In some way, somewhere, we have to workhard in our vitality, that is pertinent. Our existence is a struggle so we could not abscond from it. Whenever we attempt to abscond, we could abscond from a person but we could not abscond from ourselves. For the time has been, we could pacify ourselves but inside us, there are lots of questions. There are fights between decisions and alternatives.

In the body, there are fights between healthy bacteria and ill health causing bacteria. You would have observed there are fights between brightness and darkness constantly. In life, we examine there are opportunities for what we wish to achieve and if we lag behind there are failures. As we cross the hurdles of several disrespect to gain some respect. To become successful, we have to visage so many failures.

Endeavour never ends. Until, when there is last breath, the exertion continues. There is no get away from it. As virile as, the will power, one would strive well. Those who are weak, they are suppressed. The mighty and qualified would triumph. Thereby, you ought to be effective and have powers. As you have to appear in the confrontations, you have to make yourself strongest. Supernatural being has granted specific talent to each human being. After resisting a lotof troubles by every individual, that positive energy is accumulated and it blasts. That blast comes forward in the form of opposition.

Ravan had numerous types of authorities and ownerships. No one had been able to defend him and no one has been able to counter him for conversation, only his real brother has approached him. Vibhishun has announced in the court of Ravana as an emperor that, "Your abduction of Sita will not give you any fame. Your forefathers will repent for yourdeeds. This time you are not able to comprehend that what should be the correct action to be performed by you since all your subordinates have considered you praiseworthy. They have hidden the reality from you. Currently, I am the person who is genuinely notifying you the truth. Confirmation of the truth is not only the criterion; your welfare and our brotherhood are the reasons that made me stand in front of you". 


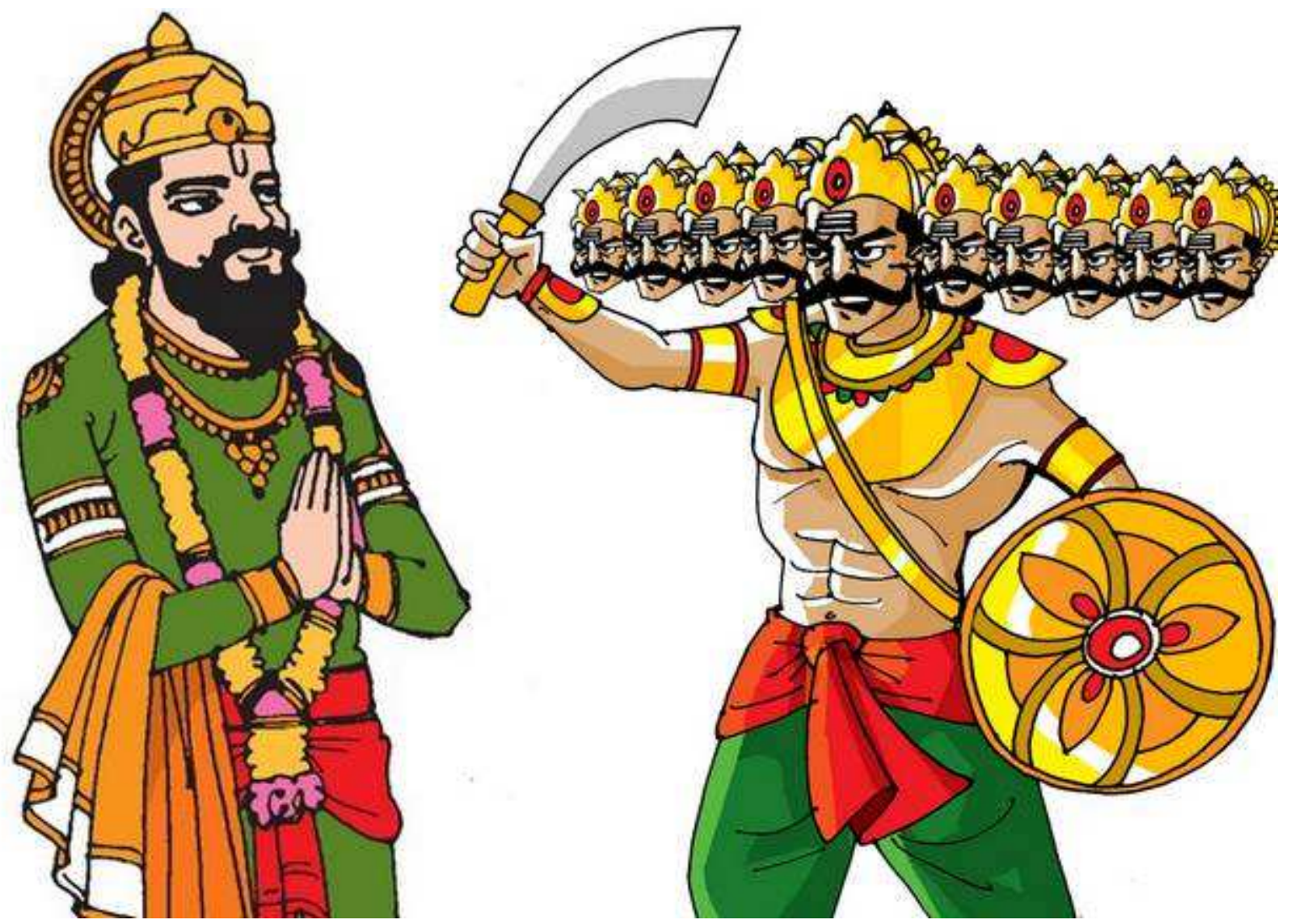

Figure 2: Vibhishan Requests Angry Ravan.

Ravan has kicked off Vibhishan because he wished to liberate Sita from Ravan's abduction. Ravana has expelled him from the country. All the groups in King's court have acknowledged deeply that Ravan has not taken the fair step. Similarly, in Duryodhan's side, there has been also a brother named Vikarn who has challenged Duryodhana, "You are sowing the seeds of destruction, it is easy to sow such seeds but it's very difficult to reap such harvests. You would not get good results of it".

You should have the supremacy to clash against the unfair and unjust occurrences. If you are a teacher and you are associated with knowledge, consequently, you should for most of the times teach and remove ignorance. If you are like a soldier, subsequently, you should continually be ready to brawl against enemies and wrong people. If you are a businessman and you earn money, thus you should frequently provide the increment of things where goods are scarce. If you are a labourer, hence you ought to constantly overcome laziness. Some people are careless; you should come in the first stance to do the welfare of the society.

"O Arjun, You are a great warrior who could weaken the enemy? How you could be a coward? How you could be impotent? Recognize your influences. The emptiness, which has crept inside your heart, has made you pathetic. Leave the narrow mindedness from your compassion. O fighter! O valiant follow your path"!

Very affable conversation to Lord Hanuman for example -

Hey Hanumanji! There is the fire inside you! You have brightness like the Sun in you! You have the patience like Mother Earth within you! You have the calmness of water internal you! Air blows very fast that fastness is inner you! You are special! The puissance of all deities is innermost you! Accept your vigour. Oh, MarutiNandan! The son of Air God! 
Wake up because we need you! Later on, your history will be world-famous for ecstasy and inspiration! This is the moment to arise and awake. As these lines are recited, his efficiency got increased. Hanumanji has become strengthened with his stamina. He jumped into the sea and crossed the deep waters to reach Sri Lanka.

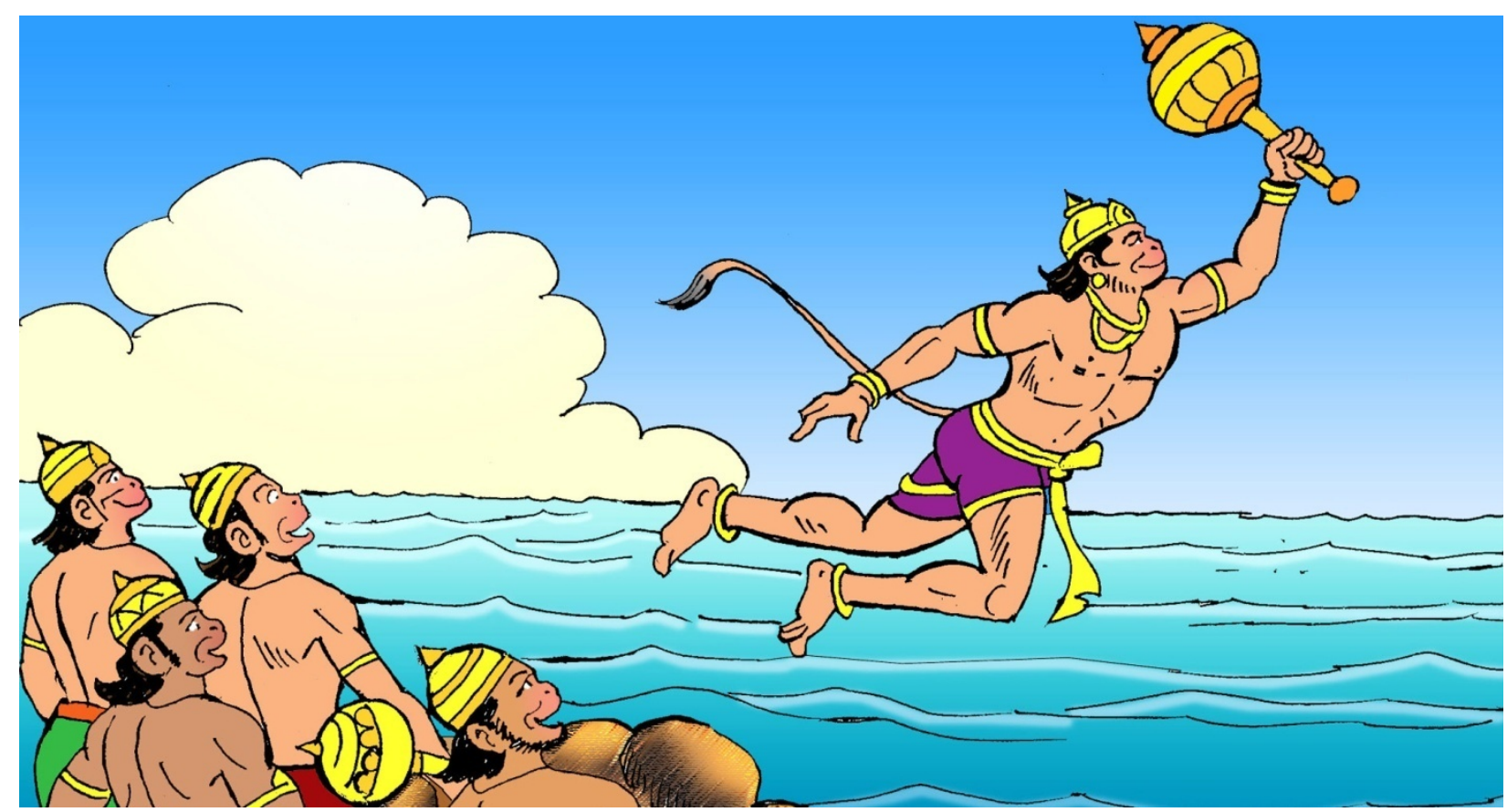

Figure 3: Hanumanji Crossing Ocean.

If we are vigilant, we will come across that intrinsically every living being has ascendancies lie in a dormant state. Someone special is required to awaken that individual. Then, he would jump and it is not that difficult to cross this worldly ocean. Krishna emphasis, "Acquire encouragement from Lord Hanumanji! O Arjun, the best combatant! Get up and stand in attention"!

Similar discourse in Katho Upanishad is by Yama to Nachiketa, "Arise, awake, obtain that which is worth fetching for you". This life is like a knife's edge, we have to be very conscious while walking over it. We could never be lazy. We are required to do, great deeds and many efforts. A few very nice lines of Katho Upanishads:

Do efforts for your goals, which are the aspirations of your existence? Worldly perception is helpful for those persons who are awakened. Ones who attempted to arisen themselves, those persons are sober. Divine music flows in their brains, they attain greatness. The first step is to wake up. These lines are from Upanishads - If you are lethargic, slipshod and do not perform your duties and you are asleep in these carnal pleasures, your Kalyugor worst time has initiated.

If you have started moving around and ruminated that you have toup rise, it is too much, what had happened, it has gone, and your past has not been alright. You are not here to get entangled in these problems; those problems are excessive love, affection, motherhood and paternal love. You have to overcome these quagmires. If you want to be great as these self - consultations have arisen in your mind. You have become conscious of your thoughts. Kalyug has gone means your worst time has gone. Your Dwaparyug has started means you are in feeling alright from before.

As you have sat down and taken an oath to achieve your goal. From today onwards, your routine has been set. You have thought in your mind, daily, I will spend my time properly. I would not waste my time. I will not pass my time in useless chat. The time which has to be spent on earning money, I will spend that time in earning money. The time which 
has to be spent on physical fitness, I will spend that time in physical fitness. When, I will sit for meals, firstly, I will decide whether the meal is tasty or nutritious. I will not consider the taste of my tongue. I wish to live a healthy life, so I will take nourishing food. If you have these deliberations in your mind and you are sitting firm than think your Tretayug or the good time has been ongoing.

When you get ready and started working, then it is said, Kalyug, Dwapar, and Treta, all of them are over and your Satyugor the best time is in progress. Proceed towards Satyugi.e. your favouriteerathat is why it is necessary to wake up. For that reason, Lord Krishna has uttered in Bhagavad Gita - You should wake up, realize, get up and manage yourself.

Spiritual awakening is the most important. In the morning, how do we awaken our children from sleep? First of all, the mother sits nearby the child's forehead and rubs his or her forehead. She speaks with great love, "Get up pretty child, as soon as the child starts movements and gets ready to speak, she utters the words of obeisance herself, she says, "Good Morning, dear child", and says, "Namaste", either to her son or her daughter or both of them and greets them with great love. This awakening and blessings to the child on the forehead with deep affection is the best way to greet them in the morning. Such awakening calls will bring love in your child's heart for their parents.

Our addressed, if we call someone the way we greet them that is of prime importance. Lord Krishna Addressed Arjun by the word, "Param tap". The one who oppresses enemies, tyrants and terrorists are shivered of by this name. The ascetic who has practiced religious austerity as well as followed "tapas" abstemiousness in life, such is Arjun. If the clouds cover the sun for sometimes, we get the assumption that there is no sun. Similarly, depressive reflections have come to Arjun's consciousness. Lord Krishna expects Arjun to remove those ruminations from him.

Lord Krishna's representative is our spirit inside us? Our spirits will always tell us to awaken till when we will fall asleep? Till when this laziness will be within you? Till when you will hold responsible your circumstances for your failures. Your most accomplished acquaintances will not come to relieve you by your references. Every day your inner soul awakens you that you have to attempt very hard for your up rise, we do not listen to our inner voice. If some people tell us strictly, about our welfare, we do not want to pay attention to them, we get angry at them. We all are pleased to take note of our appreciation. Some people praise us highly; we wish to notice them. This is the way which would lead to our downfall. We must come out of this approach.

Lord Krishna told Arjun, "You are warrior, brawl bravely, does not act like a coward or an impotent". Sometimes we have to give a shock to the person to get awakened. We have to speak harsh words to the person for his uprising. The way we condemn others, we lose our lots of potential in claiming others as wrong. Instead of that, if sometimes we criticize ourselves, we mock at ourselves with anger. If we scold ourselves, if we clash with ourselves, therefore the contentment, we will gain that we could improve ourselves. It is not a good deal to fight with others because we could not improve others. Then love yourself and praise yourself highly for your good accomplishments. It is appreciable to explicate ourselves that whatever has occurred that will not get repeated. There will be a new life, a new beginning. Divine spiritbestows us every new day. It must be our daily practice that we should work for our renewal.

\section{REFERENES}

1. Agnipuran.net

2. BhagvadGita.net

3. C. Rajgopalchari. Mahabharat, Mumbai: BhartiyaVidyaBhawan Press. 2015. Print. 
4. Muralikrishna, Dantu. "Habits In Life-from Bhagavad Gita."International Journal of Educational Science and Research (IJESR) 9. 5, Oct 2019, 1-8

5. C. Rajgopalchari, Ramayan, Mumbai: BhartiyaVidyaBhawan Press.2013. Print.

6. "Om NamoBhagavateVasudevaya - Moksha (Liberation Mantra) meaning",

7. www.Awakeningstate.com 2020 Web 17 Feb 2020.

8. Gupta, Rashmi, and Jaya Tripathi Mishra. "RabindraNath Tagore's The King of the Dark Chamber: Soul's Relentless Journey for Unison with Divine." International Journal of English and Literature (IJEL) 4.1 (2014): 45-50.

9. www.awakeningstate.com/spiritual-awakening/com... Web 17 Feb 2020.

10. “Nachiketa's -Dialogue -with- Lord- of-Death”, Speaking Tree.com. 2020 Web 23 August 2020.

11. https://www.speakingtree.in/blog/nachiketas-dialogue-with-lord-of-death Web 23 August 2020.

12. “Overcoming - Obstacles”.Jnana.com 2020 Web 24 Aug 2020.

13. LATIF, SHAHID, and ABDUL QADIR MUSHTAQ. "DARA SHIKOH: MYSTICAL AND PHILOSOPHICAL DISCOURSE. "International Journal of History and Research (IJHR) 3. 2 Jun 2013, 17-24

14. https://www.jnana.com/blog/overcoming-obstacles/Web24Aug2020.

15. "Ramayana: Asia Society". Asiasociety.org. 2020 Web 17 Feb 2020.

16. https://asiasociety.org/education/ramayan.Web 17 Feb 2020

17. Ramayan.net.

18. www.ReSanskrit.com 2020 Web 07 July 2020.

19. Singh, S. A. T. Y. A. P. A. L. "Yoga: an answer to lifestyle disorders." Int J Applied Natural Sci 5 (2016): 27-34.

20. https://resanskrit.com/bhagavad-gita-most-useful-quotes-hindi-english/

21. "Shastra: Hindu Scriptures". Hinduonline.com 2020 Web 13 Jan 2020.

22. http://hinduonline.co/Scriptures/Shastras.html.Web13Jan2020.

23. Sudhanshuji Maharaj.net.

24. Swami, Prabhipada, A. C. Bhaktivedanta. Bhagavad Gita as it is, Watford: ISKON Reader Services, 2010. Print.

25. "Vedanta Concepts and Application", Kolkata: Ramkrishna Mission Institute of Culture, 2000. Print. 
